\title{
Preface: Impacts of extreme climate events and disturbances on carbon dynamics
}

\author{
Jingfeng Xiao ${ }^{1}$, Shuguang Liu ${ }^{2}$, and Paul C. Stoy ${ }^{3}$ \\ ${ }^{1}$ Earth Systems Research Center, Institute for the Study of Earth, Oceans, and Space, University of New Hampshire, Durham, \\ NH 03824, USA \\ ${ }^{2}$ U.S. Geological Survey (USGS) Earth Resources Observation and Science (EROS) Center, Sioux Falls, SD 57198, USA \\ ${ }^{3}$ Department of Land Resources and Environmental Sciences, Montana State University, Bozeman, MT 59717, USA
}

Correspondence to: Jingfeng Xiao (j.xiao@unh.edu)

Received: 11 January 2016 - Published in Biogeosciences Discuss.: 17 February 2016

Revised: 15 May 2016 - Accepted: 27 May 2016 - Published: 22 June 2016

\begin{abstract}
The impacts of extreme climate events and disturbances $(E C E \& D)$ on the carbon cycle have received growing attention in recent years. This special issue showcases a collection of recent advances in understanding the impacts of ECE\&D on carbon cycling. Notable advances include quantifying how harvesting activities impact forest structure, carbon pool dynamics, and recovery processes; observed drastic increases of the concentrations of dissolved organic carbon and dissolved methane in thermokarst lakes in western Siberia during a summer warming event; disentangling the roles of herbivores and fire on forest carbon dioxide flux; direct and indirect impacts of fire on the global carbon balance; and improved atmospheric inversion of regional carbon sources and sinks by incorporating disturbances. Combined, studies herein indicate several major research needs. First, disturbances and extreme events can interact with one another, and it is important to understand their overall impacts and also disentangle their effects on the carbon cycle. Second, current ecosystem models are not skillful enough to correctly simulate the underlying processes and impacts of ECE\&D (e.g., tree mortality and carbon consequences). Third, benchmark data characterizing the timing, location, type, and magnitude of disturbances must be systematically created to improve our ability to quantify carbon dynamics over large areas. Finally, improving the representation of ECE\&D in regional climate/earth system models and accounting for the resulting feedbacks to climate are essential for understanding the interactions between climate and ecosystem dynamics.
\end{abstract}

\section{Introduction}

The biosphere plays an important role in regulating atmospheric carbon dioxide concentrations and thereby climate. Extreme climate events such as drought (Xiao et al., 2009; Zhao and Running, 2010) and heat waves (Ciais et al. 2005) and disturbances such as fire (Bowman et al., 2009), hurricanes (Chambers et al., 2007; Dahal et al., 2014; Xiao et al., 2011), wind storms (McCarthy et al., 2006), and insect outbreaks (Kurz et al., 2008a) can substantially alter ecosystem structure and function and influence terrestrial carbon dynamics. Extreme climate events and disturbances (ECE\&D) are projected to increase in both frequency and severity during the remainder of the 21 st century (IPCC, 2013), with important consequences for terrestrial carbon cycling. Projecting the impacts of these future events remains a challenge given the substantial uncertainty in forecasting these events and the insufficient representation of ECE\&D in ecosystem and land surface models. A better understanding of the impacts of ECE\&D on carbon dynamics across different ecosystems is essential for projecting ecosystem responses to future climate change and feedbacks to the climate system.

Biospheric carbon fluxes often exhibit pronounced interannual variability (IAV) and ECE\&D are believed to be primary sources of the IAV (Eimers et al., 2008; Reichstein et al., 2013; Xiao et al., 2014), which can be pronounced. For example, gross primary productivity (GPP) exhibited significant IAV over the period 2000-2014 on the global scale as identified by the MODIS GPP product (Zhao et al., 2005), 


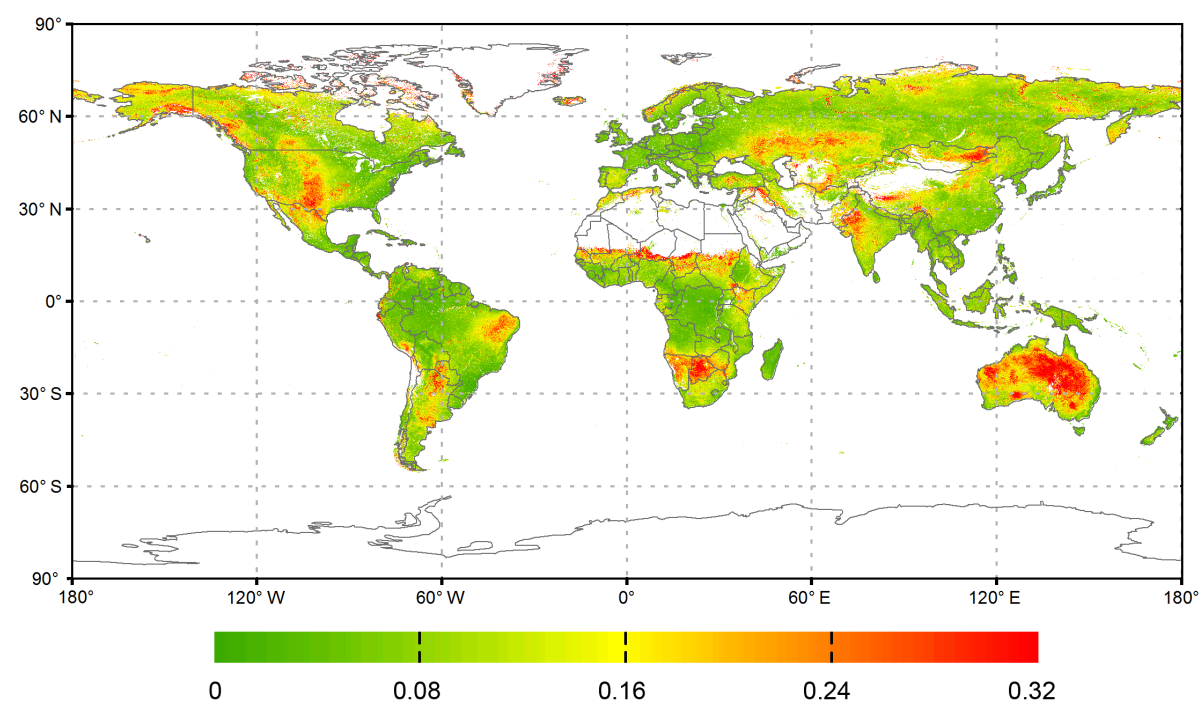

Figure 1. The interannual variability (i.e., the coefficient of variation or CV) of annual gross primary productivity (GPP) over the period 2000-2014 from the MODIS GPP product (MOD17A3). The CV is unitless.

with important regional differences (Fig. 1). The IAV is measured by the coefficient of variation (CV), defined as the standard deviation divided by the mean. Australia and southern Africa had the largest IAV; the US Great Plains, the southwestern USA, Alaska, India, part of the Tibetan Plateau, the eastern Mongolia, Kazakhstan, the Sahel region, and the eastern Amazon had intermediate IAV; the remaining regions had relatively low IAV.

ECE\&D can lead to exceptionally high or low annual carbon fluxes. We used the annual GPP data from the MODIS GPP product (Zhao et al., 2005) to identify extreme GPP values (outliers) that exceed the statistical normal range presumably caused by extreme climate events and/or disturbances (Fig. 2). For each grid cell, the outliers of annual GPP over the period 2000-2014 were identified using interquartile range (IQR) and quartiles (Q1: 25\% quartile; Q3: $75 \%$ quartile). The outliers on the higher end were determined as values beyond $\mathrm{IQR}+1.5 \times \mathrm{Q} 3$, and the outliers on the lower end were identified as values below IQR $-1.5 \times \mathrm{Q} 1$. Outliers on the lower end were observed in parts of Europe, Russia, North America, the Amazonia, and Africa (Fig. 2). These exceptionally low annual GPP were likely caused by drought, extreme low temperature, fire disturbance, or harvesting. Outliers on the higher end were observed in Alaska, the southwestern USA, Australia, and parts of the Amazonia and southern Africa (Fig. 2). These exceptionally high annual GPP were likely caused by exceptionally moist conditions and/or warm temperatures. The US Great Plains and Kazakhstan had large IAV and outliers on the lower end; part of Australia and southern Africa also exhibited large IAV but had outliers on the higher end; the large IAV of GPP did not correspond to outliers for other regions (Figs. 1 and 2). The
IAV of carbon fluxes was likely driven by both outliers and moderate to strong anomalies in fluxes.

The impacts of ECE\&D on carbon dynamics have received growing attention. We searched through a number of journal articles on these topics using Web of Science (Fig. 3) and found a total of 497 and 1593 journal articles for extreme climate events and disturbances, respectively, over the period from 2000 to 2015. Notably, the annual number of publications on the impacts of these events on carbon dynamics has been growing at an average rate of 18 articles per year from 2000 to 2015 and at an average rate of 25 articles per year over the past decade (2006-2015), emphasizing the growing scientific interest in these important topics.

Various approaches have been used to assess the impacts of ECE\&D on ecosystem carbon dynamics. At the ecosystem scale, in situ methods including field experiments (Barbeta et al., 2013), long-term observations (Turner et al., 2003), and the eddy covariance technique (Amiro et al., 2010; Schwalm et al., 2010) help us to understand the mechanisms underlying responses of ecosystem processes to ECE\&D. Modeling approaches including process-based ecosystem models (Liu et al., 2011) or data-driven upscaling approaches (Jung et al., 2009; Xiao et al., 2008) have been used for regional to global assessments, which also rely heavily on satellite remote sensing (Xiao et al., 2014). Synthesizing these findings is an ongoing challenge, and multiple approaches are required to understand the consequences of different ECE\&D for carbon cycling.

Spatially, the locations of the previous research activities have been largely aligned with the geography of the occurrence of ECE\&D. For example, we have witnessed pronounced impacts of insect outbreaks and fires in the northern Rocky Mountains (Hicke et al., 2012; Kurz et al., 2008b; 

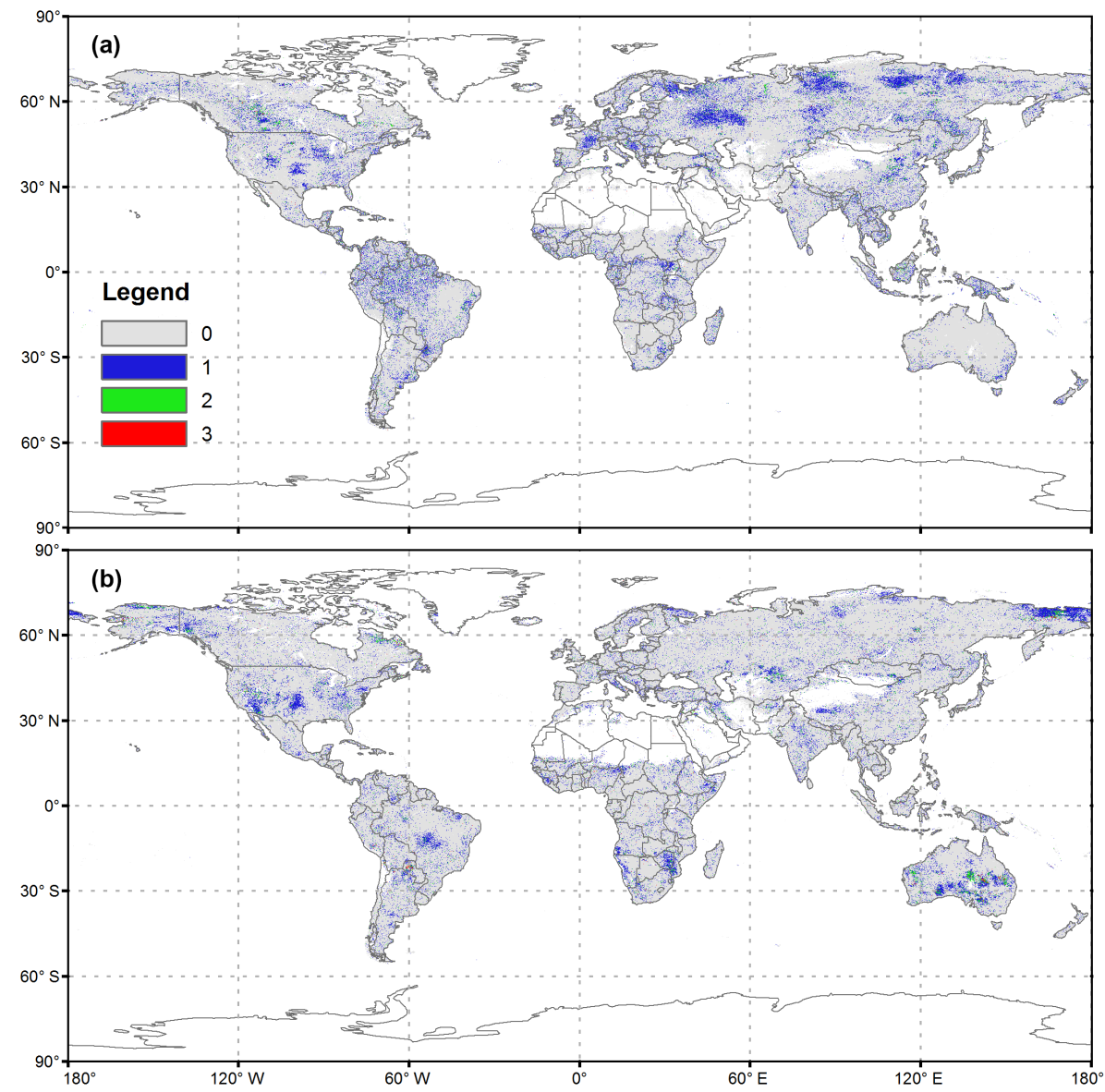

Figure 2. The number of extreme years characterized by the number of outliers of the annual gross primary productivity (GPP) distribution over the period 2000-2014: (a) outliers on the lower end (i.e., exceptionally low annual GPP); (b) outliers on the higher end (i.e., exceptionally high annual GPP). The outliers were identified using interquartile range (IQR) and quartiles (Q1: $25 \%$ quartile; Q3: $75 \%$ quartile) with the outliers on the higher end determined as values beyond $\mathrm{IQR}+1.5 \times \mathrm{Q} 3$ and the outliers on the lower end determined as values below IQR $-1.5 \times \mathrm{Q} 1$. The annual GPP values $\left(\mathrm{g} \mathrm{C} \mathrm{m}^{-2}\right.$ year $\left.^{-1}\right)$ were derived from the MODIS GPP product (MOD17A3).

Law et al., 2004), the widespread deforestation in Amazon and other tropical regions (Achard et al., 2014; DeFries et al., 2002; Harris et al., 2012), peatland fires in Indonesia (Page et al., 2002; Turetsky et al., 2015), tropical cyclones in the USA (Dahal et al., 2014), and drought and heat waves in Europe (Bréda et al., 2006; Ciais et al., 2005; Reichstein et al., 2007) and the southwestern USA (Allen et al., 2010; Carnicer et al., 2011; Zeppel et al., 2013). Temporally, most of the research has been on the impacts of individual ECE\&D, with fewer studies involving long-term observations and monitoring records (Dahal et al., 2014; Seidl et al., 2014). Abundant evidence has been collected globally in the past decades on increased tree mortality resulting from climate events such as prolonged mega droughts and heat waves (Allen et al., 2010; McDowell, 2011; Meddens et al., 2015; Meir et al., 2015). However, the mechanisms behind this increased mortality and the consequences of carbon dynamics still remain to be unveiled (Meddens et al., 2015; Meir et al., 2015).
The present special issue is the outcome of special sessions on the impacts of ECE\&D on carbon dynamics at the American Geophysical Union Fall Meeting (2011-2013). This issue consists of 17 articles: 6 on extreme climate events and 11 on disturbances. This special issue, along with the special issue on climate extremes and biogeochemical cycles in Biogeosciences (Bahn et al., 2015), reflects recent advances in assessing how ECE\&D influence terrestrial carbon cycling. We feel that the authors have provided a timely and valuable contribution to the research communities of carbon cycle and global change.

\section{Methods and findings}

We highlight the findings in this special issue by grouping manuscripts that emphasize the impacts of drought and extreme precipitation events, herbivory (namely insect outbreaks), fire, interactions between herbivory and fire, natural 

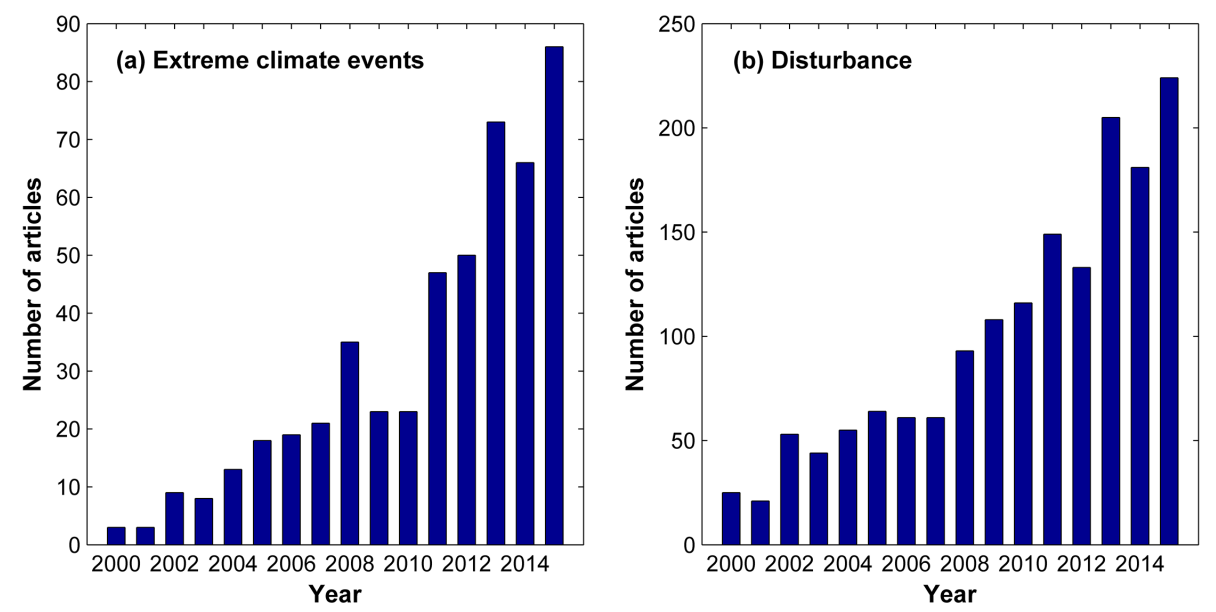

Figure 3. The number of journal articles published over the period from 2000 to 2015 as identified by Web of Science ${ }^{\mathrm{TM}}$ as of 14 April 2016 for the impacts of (a) extreme climate events and (b) disturbance on carbon dynamics. The combination of key words that we used to represent "extreme climate events" is the following: TS = (extreme climate events" OR "climate extremes" OR drought OR "extreme precipitation") AND TS = (“carbon dynamics" OR “carbon cycle" OR "carbon flux" OR "carbon stock" OR "carbon pool”), where TS stands for Topic. The combination of key words used to represent "disturbance" is the following: TS = (disturbance OR fire OR harvesting OR logging OR hurricane or "insect outbreaks") AND TS = ("carbon dynamics" OR "carbon cycle" OR "carbon flux" OR "carbon stock" OR “carbon pool”).

hazards (e.g., hurricanes and typhoons), and forest management.

\subsection{Drought and extreme precipitation events}

Piayda et al. (2014) quantified the impacts of the extreme drought event in 2012 on carbon and water cycling in a Mediterranean woodland. The drought reduced overstory GPP in 2012 by $28 \%$ and carbon-sink strength by $38 \%$ compared to 2011. Results indicated that successful simulation of drought effects on the montado ecosystem requires the incorporation of variable apparent maximum carboxylation rate, stomatal conductance, and vapor pressure deficit sensitivity into photosynthesis-stomatal conductance modeling.

The simulations of a process-based ecosystem model showed that drought from 2000 to 2011 led to significant reduction in both GPP and net ecosystem productivity (NEP) of China's terrestrial ecosystems at regional to national scales (Liu et al., 2014). Relative to the long-term mean, the nationwide annual NEP in 2001, 2006, 2009, and 2011 decreased by ca. $63,88,170$, and $61 \mathrm{TgC} \mathrm{yr}^{-1}$, respectively, due to droughts (Liu et al., 2014). These two studies were consistent with several previous synthesis and modeling studies indicating that severe droughts could reduce annual GPP and NEP, and the reduction in NEP was largely driven by the decrease in GPP due largely to reductions in GPP (Ciais et al., 2005; Schwalm et al., 2010; Xiao et al., 2009).

The opposite of drought - extreme precipitation events have received less attention in carbon cycle studies. Jiang et al. (2013) conducted a field experiment in three subtropical forests to study the responses of soil respiration to both drought and extreme high precipitation and found that altered precipitation strongly influenced soil respiration not only by controlling soil moisture but also by modifying moisture and temperature sensitivity of soil respiration. Their results indicate that soil respiration was more sensitive to soil moisture in the presence of drought, and higher precipitation in the wet season could have a limited effect on the response of soil respiration to rising temperatures (Jiang et al., 2013).

Zeppel et al. (2014) reviewed studies of extreme precipitation and seasonal changes in precipitation on carbon metabolism in grassland and forested ecosystems. They found that extremely high precipitation is likely to increase aboveground net primary productivity (ANPP) of xeric biomes and reduce ANPP of mesic biomes. Changes in precipitation during the growing season are likely to have a greater impact on carbon cycle dynamics than precipitation during the non-growing season (Zeppel et al., 2014). These studies indicated that the direction and magnitude of the impacts of extreme precipitation events on carbon fluxes depend on the season (wet vs. dry) and biome type (xeric vs. mesic).

\subsection{Extreme temperature events}

Extreme temperature events have been a feature of recent climate change, especially at high latitudes (IPCC, 2013). Previous studies showed that extreme temperature events often reduce GPP and NEP of terrestrial ecosystems (Ciais et al., 2005; Qu et al., 2016). The effects of extreme temperature on the carbon dynamics of aquatic ecosystems, however, have received little attention. Pokrovsky et al. (2013) studied the impacts of the $5-15^{\circ} \mathrm{C}$ summer warming event of 
2012 on the carbon dynamics of thermokarst lakes in western Siberia. Dissolved organic carbon concentrations increased by a factor of 2 as a result of the warming event despite limited changes in conductivity and $\mathrm{pH}$, and the concentration of dissolved methane increased by nearly 5-fold (Pokrovsky et al., 2013). These results demonstrate a substantial increase in the methane emission capacity from lakes as a result of summertime warming in areas of permafrost thaw.

De Simon et al. (2013) examined the effects of manipulated warmer or cooler late winter-early spring conditions on the carbon budget and yield of soybean crops. Their results demonstrate that extreme temperature events in late winter did not result in significant changes in the net carbon balance (De Simon et al., 2013). These events may have larger impacts on natural ecosystems by advancing or delaying leafout dates.

Combined, these studies indicate that the effects of extreme temperature events on ecosystem carbon dynamics depend on the timing and magnitude of these events. Extreme temperature events occurring in the growing season could substantially alter carbon fluxes, while those events occurring during the remainder of the year had smaller effects than expected.

\subsection{Insect outbreaks}

The coniferous forests of western North America have experienced an unprecedented herbivore outbreak over millions of hectares over the past decades (Hicke et al., 2012; Raffa et al., 2008), where part of the global tree die-off is due to the combined effects of elevated temperatures, drought, and associated herbivory (Allen et al., 2010). Measurements of the impacts of this disturbance at the site scale find minimal ecosystem carbon loss or even net uptake shortly after eruptive herbivory (Brown et al., 2010), which contrasts regional estimates of substantial carbon losses to the atmosphere (Ghimire et al., 2015; Kurz et al., 2008a). Mathys et al. (2013) in this issue used the eddy covariance technique to study carbon dioxide flux after a mountain pine beetle (Dendroctonus ponderosae, Hopkins) attack over a 2-year period and compared these to an adjacent clear-cut. They found that the mountain pine beetle-damaged forest was a carbon sink of ca. $50 \mathrm{~g} \mathrm{C} \mathrm{m}^{-2}$ year $^{-1} 2$ years after attack. This study also indicates that the residual forest and the understory vegetation contributed to carbon uptake and could enable the forest to return to carbon neutrality at a faster rate than clearcuts. The impacts of herbivore outbreak depend on the type of herbivore (e.g., foliavores vs. phloem-feeders) and the intensity of disturbance (Allen et al., 2010; Brown et al., 2010; Ghimire et al., 2015; Hicke et al., 2012; Kurz et al., 2008a; Mathys et al., 2013; Raffa et al., 2008).

\subsection{Fire}

Fire causes direct and immediate carbon emissions into the atmosphere from biomass burning (the direct effect), and subsequent changes in NEP (the indirect effect) through changes in GPP and ecosystem respiration of the remaining live stand and the heterotrophic respiration of the damaged biomass. Li et al. (2014) in this special issue provided a quantitative assessment of the direct and indirect impacts of fire on the net carbon balance of global terrestrial ecosystems during the 20th century. Their results show that fire decreased the net carbon gain of global terrestrial ecosystems by $1.0 \mathrm{Pg} \mathrm{C} \mathrm{yr}^{-1}$ averaged across the 20th century, as a result of the fire direct effect $\left(1.9 \mathrm{PgC}_{\mathrm{yr}}{ }^{-1}\right)$ partly offset by the indirect effect $\left(-0.9 \mathrm{Pg} \mathrm{C} \mathrm{yr}^{-1}\right)$. The effect of fire on the net carbon balance significantly declined until 1970 with a trend of $8 \mathrm{Tg} \mathrm{Cyr}^{-1}$ due to an increasing indirect effect, and increased subsequently with a trend of $18 \mathrm{Tg} \mathrm{C} \mathrm{yr}^{-1}$ due to an increasing direct effect ( $\mathrm{Li}$ et al., 2014). These results help constrain the global-scale dynamics of fire and the terrestrial carbon cycle.

\subsection{Insect outbreaks vs. fire}

At the regional scale, Caldwell et al. (2013) simulated and evaluated the long-term impacts of the two characteristic disturbances in the southern Rocky Mountain forests (i.e., the outbreak of mountain pine beetle and high-severity wildfire) on changes in species composition and carbon stocks. Wildfire caused larger changes in both patterns of succession and distribution of carbon among biomass pools than did mountain pine beetle disturbance; carbon in standing live biomass returned to pre-disturbance levels after 50 vs. 40 years following wildfire and mountain pine beetle disturbances, respectively (Caldwell et al., 2013).

Clark et al. (2014) used the eddy covariance technique to study the impacts of fire and gypsy moth (Lymantria dispar L.) disturbance in oak-dominated, pine-dominated, and mixed forests in eastern North America. The net ecosystem exchange (NEE), GPP, and water use efficiency were of greater magnitude in the oak-dominated forest before disturbance during summer. Water use efficiency declined by $60 \%$ at the oak-dominated stand and by nearly $50 \%$ at the mixed stand after a gypsy moth disturbance, but prescribed fire had little impact on water use efficiency in the mixed or pine stands (Clark et al., 2014). These results demonstrate the importance of forest type, disturbance type, and time since disturbance on coupled carbon and water cycle functioning in temperate forests.

\subsection{Hurricanes and typhoons}

Hurricane events in the USA have significant effects on regional carbon dynamics (Dahal et al., 2014). Typhoons are natural disturbances to subtropical mangrove forests in Asia, 
and their effects on ecosystem carbon dynamics of mangroves are not well understood. Chen et al. (2014) examined the short-term effects of frequent strong typhoons on defoliation and the NEE of subtropical mangroves. The responses of daily NEE following typhoons were highly variable in mangrove ecosystems (Chen et al., 2014), demonstrating that the characteristics of the typhoon and antecedent ecosystem conditions are important for understanding hurricane impacts on carbon stocks and fluxes. Severe hurricanes and typhoons that destroy a large number of trees could have significant effects on regional carbon cycling, while those that lead merely to defoliation likely had transient effects on ecosystem carbon exchange.

\subsection{Forest management}

Accurate quantification of the effects of partial cutting or clear-cutting is essential for a better understanding of forest carbon dynamics and for informing forest management. Zhou et al. (2013a) conducted a meta-analysis on the impacts of partial cutting (i.e., cutting events with aboveground biomass removal rate $<90 \%$ ) on forest carbon stocks by collecting data on cutting intensity, forest structure, and carbon stock components. This is a global-scale meta-analysis, but the majority of the sites are distributed in the USA and Europe. The results showed that partial cutting reduced aboveground carbon by $43 \%$ and increased understory carbon storage by nearly $400 \%$ on average, but did not have significant effects on forest floor or mineral soil carbon stocks (Zhou et al., 2013a). This effort provides a new perspective on the impacts of forest harvesting as it covers the spectrum of harvest disturbances from partial cutting to clear-cut and goes beyond previous reviews that mostly concentrated on the impacts of clear-cutting (Johnson and Curtis, 2001; Nave et al., 2010). The impacts of partial cutting can be significant; for example, partial cutting accounted for about three-quarters of the total $\mathrm{C}$ loss from timber harvesting in the eastern USA from 2002 to 2010 (Zhou et al., 2013b).

Wang et al. (2014) used a process-based forest ecosystem model, PnET-CN, to evaluate how clear-cutting alters ecosystem carbon fluxes, biomass, and leaf area index in northern temperate forests. They found that harvest disturbance in northern temperate forests had significant effects on forest carbon fluxes and stocks, and increased harvesting intensity would delay the recovery of NEP. Evergreen needleleaf forests were slower to recover to full carbon assimilation capacity after stand-replacing harvests than deciduous broadleaf forests (Wang et al., 2014). Future modeling studies of disturbance effects should incorporate forest population dynamics (e.g., regeneration and mortality) and relationships between age-related model parameters and state variables (e.g., leaf area index).

\subsection{Disturbance legacy}

The time since disturbance is an important controlling factor of carbon dynamics. Berryman et al. (2013) tested the impacts of experimental pinyon pine (Pinus edulis Englem.) mortality on microbial respiration. They found that litter respiration responded to water availability at both treatment and control sites, and that soil respiration decreased at the site with experimental mortality. These results demonstrate ecosystem-level consequences of tree mortality that differs as a function of water availability (Berryman et al., 2013).

Yue et al. (2013) compared observations from post-fire vegetation trajectories in the boreal forest with simulations from the process-based ORCHIDEE (Organizing Carbon and Hydrology In Dynamic Ecosystems) vegetation model and supported the notion that the increase in atmospheric $\mathrm{CO}_{2}$ concentrations and vegetation recovery were jointly responsible for current carbon-sink conditions. It should be noted that nitrogen deposition - a global change factor enhancing ecosystem carbon uptake was not explicitly considered, although the effects of nitrogen deposition carbonsink strength have been controversial (Magnani et al., 2007; Nadelhoffer et al., 1999). Nevertheless, their results highlight the importance of understanding how global change and disturbance events interact to determine current - and likely future - carbon cycle dynamics (Yue et al., 2013). These two studies demonstrate that the legacy of disturbance and environmental factors jointly control the carbon dynamics following disturbance.

Modeling approaches have been widely used to simulate ecosystem carbon dynamics following disturbance. In this special issue Wang et al. (2014) simulated the dynamics of carbon fluxes and stocks following harvest. The simulated NEP and aboveground carbon stock after clear-cuts generally followed the hypothesized trajectories (Chapin, 2011; Odum, 1969) while the decline in NEP was due to relatively stable GPP and gradually increasing ecosystem respiration (ER). Evergreen needleleaf forests recovered more slowly from a net carbon source to a net sink, and lost more carbon than deciduous broadleaf forests.

Disturbance-induced tree mortality regulates the forest carbon balance, but tree mortality and its carbon consequences are not well represented in ecosystem models (Bond-Lamberty et al., 2015). Bond-Lamberty et al. (2015) tested whether three ecosystem models - the classic bigleaf model Biome-BGC (BioGeochemical Cycles) and the gap-oriented models ZELIG, a gap model, and ED (ecosystem demography) - could reproduce the resilience of forest ecosystems to moderate disturbances. The models replicated observed declines in aboveground biomass well but could not fully capture observed post-disturbance carbon fluxes. This study indicates that ecosystem models are yet unable to correctly simulate the effects of disturbances.

Lack of critical geospatial data on disturbances and associated impacts on ecosystems has been identified as one 
of the main challenges in quantifying carbon dynamics over large areas (Liu et al., 2011). Recently, a continental-scale forest stand age map was developed for North America using forest inventory data, large fire data, and remotely sensed data, providing a new source of information that can benefit quantification of the carbon sources and sinks across the continent and contribute to studies of disturbance (Pan et al., 2011). Deng et al. (2013) in this special issue used these continental-stand age maps as an additional constraint to atmospheric $\mathrm{CO}_{2}$ inversions. They found that regions with recently disturbed or old forests are often nudged towards carbon sources while regions with middle-aged productive forests are shifted towards sinks, confirming stand age effects observed from many eddy covariance flux towers (Deng et al., 2013). These results were generally consistent with the synthesis results from eddy covariance flux data across North America (Amiro et al., 2010) but they were inconsistent with some other studies showing that old-growth forests were still carbon sinks (Desai et al., 2005; Luyssaert et al., 2008). At the sub-continental level, their inverted carbon fluxes agreed well with continuous estimates of NEE upscaled from eddy covariance flux data (Xiao et al., 2008, 2011). Recent development in characterizing the timing, location, type, and magnitude of disturbances (Huang et al., 2010; Kennedy et al., 2010; Masek et al., 2013; Williams et al., 2014; Zhu and Woodcock, 2014) are helping to advance diagnosis and monitoring of carbon dynamics over large areas.

\section{Conclusions}

The contributions of this special issue reflect some of the most recent advances in the impacts of ECE\&D on carbon dynamics. These studies address the impacts of different types of extreme events including forest management, hurricanes and typhoons, drought, extreme precipitation events, extreme temperature events, insect outbreaks, and fire as well as ecosystem recovery since disturbance. The direction and magnitude of the effects of these events on ecosystem carbon fluxes depend on the nature of the events (type, duration, and intensity), the timing of the events (e.g., wet vs. dry season, summer vs. winter), and the biome type (e.g., xeric vs. mesic). These events typically have negative effects on net carbon uptake while some events such as extreme precipitation events may also have positive effects on net carbon uptake depending on antecedent conditions and the nature of the extreme events.

Importantly, studies in this special issue collectively indicate several major research needs. First, ECE\&D can interact with one another, and it is important to disentangle their relative effects on the carbon cycle. Second, current ecosystem models in general are not skillful enough to correctly simulate the impacts of ECE\&D such as disturbance-induced tree mortality and its carbon consequences, and therefore ecosystem models must be improved to correctly represent the un- derlying processes and impacts (Liu et al., 2011; Reichstein et al., 2013). For example, the processes of drought effects on ecosystem respiration are not well represented in models. Third, the lack of data on major disturbances is still one of the main challenges that hinder the improvement of quantifying carbon dynamics over large areas, and benchmark data characterizing the timing, location, type, and magnitude of disturbances must be created. With the ongoing continuous monitoring of earth surface conditions using a constellation of satellites and emerging data mining technologies, the characterization and understanding of the impacts of ECE\&D are expected to improve drastically over the next 5 to 10 years. However, major challenges still remain on how to translate those conditional changes into carbon fluxes and understand the specific roles of ECE\&D in particular. Finally, besides carbon fluxes and stocks, other biogeophysical properties such as albedo, evapotranspiration (ET), and surface energy exchange are also altered by ECE\&D. Improving the representation of ECE\&D in regional climate/earth system models and accounting for the resulting feedbacks to the climate are essential for understanding the interactions between climate and ecosystem dynamics. Ongoing research in these areas will continue to improve our emerging understanding of the impacts of ECE\&D on carbon cycling and the feedbacks to the climate.

Acknowledgements. We would like to thank all of the scientists who contributed to this special issue. Jingfeng Xiao acknowledges support from the National Science Foundation (NSF) through the Emerging Frontiers Macrosystems Biology Program (award numbers 1065777) and the National Aeronautics and Space Administration (NASA) through the Carbon Cycle Science Program (award number NNX14AJ18G), Climate Indicators and Data Products for Future National Climate Assessments (award number NNX16AG61G), and the Terrestrial Ecology Program (award number NNX12AK56G). PCS acknowledges the support of NSF Macrosystems Biology Program (award number 1241810), the NSF Division of Environmental Biology (award number 1552976), the Alexander von Humboldt Foundation, and the USDA NIFA Hatch project 228396. Shuguang Liu acknowledges the support from the U.S. Geological Survey Land Change Science Program. Any use of trade, firm, or product names is for descriptive purposes only and does not imply endorsement by the US Government. We thank M. van Oijen and an anonymous reviewer for their constructive comments on the manuscript.

Edited by: M. Bahn

\section{References}

Achard, F., Beuchle, R., Mayaux, P., Stibig, H. J., Bodart, C., Brink, A., Carboni, S., Desclée, B., Donnay, F., and Eva, H. D.: Determination of tropical deforestation rates and related carbon losses from 1990 to 2010, Glob. Change Biol., 20, 2540-2554, 2014. 
Allen, C. D., Macalady, A. K., Chenchouni, H., Bachelet, D., McDowell, N., Vennetier, M., Kitzberger, T., Rigling, A., Breshears, D. D., Hogg, E. H., Gonzalez, P., Fensham, R., Zhang, Z., Castro, J., Demidova, N., Lim, J.-H., Allard, G., Running, S. W., Semerci, A., and Cobb, N.: A global overview of drought and heat-induced tree mortality reveals emerging climate change risks for forests, Forest Ecol. Manag., 259, 660684, doi:10.1016/j.foreco.2009.09.001, 2010.

Amiro, B. D., Barr, A. G., Barr, J. G., Black, T. A., Bracho, R., Brown, M., Chen, J., Clark, K. L., Davis, K. J., Desai, A. R., Dore, S., Engel, V., Fuentes, J. D., Goldstein, A. H., Goulden, M. L., Kolb, T. E., Lavigne, M. B., Law, B. E., Margolis, H. A., Martin, T., McCaughey, J. H., Misson, L., Montes-Helu, M., Noormets, A., Randerson, J. T., Starr, G., and Xiao, J.: Ecosystem carbon dioxide fluxes after disturbance in forests of North America, J. Geophys. Res., 115, doi:10.1029/2010jg001390, 2010.

Bahn, M., Reichstein, M., Guan, K., Moreno, J. M., and Williams, C.: Preface: Climate extremes and biogeochemical cycles in the terrestrial biosphere: impacts and feedbacks across scales, Biogeosciences, 12, 4827-4830, http://www.biogeosciences.net/12/ 4827/2015/bg-12-4827-2015.pdf, 2015.

Barbeta, A., Ogaya, R., and Penuelas, J.: Dampening effects of long-term experimental drought on growth and mortality rates of a Holm oak forest, Glob. Change Biol., 19, 3133-3144, doi:10.1111/gcb.12269, 2013.

Berryman, E., Marshall, J. D., Rahn, T., Litvak, M., and Butnor, J.: Decreased carbon limitation of litter respiration in a mortality-affected piñon-juniper woodland, Biogeosciences, 10, 1625-1634, doi:10.5194/bg-10-1625-2013, 2013.

Bond-Lamberty, B., Fisk, J. P., Holm, J. A., Bailey, V., Bohrer, G., and Gough, C. M.: Moderate forest disturbance as a stringent test for gap and big-leaf models, Biogeosciences, 12, 513-526, doi:10.5194/bg-12-513-2015, 2015.

Bowman, D., Balch, J. K., Artaxo, P., Bond, W. J., Carlson, J. M., Cochrane, M. A., D’Antonio, C. M., DeFries, R. S., Doyle, J. C., Harrison, S. P., Johnston, F. H., Keeley, J. E., Krawchuk, M. A., Kull, C. A., Marston, J. B., Moritz, M. A., Prentice, I. C., Roos, C. I., Scott, A. C., Swetnam, T. W., van der Werf, G. R., and Pyne, S. J.: Fire in the Earth System, Science, 324, 481-484, doi:10.1126/science.1163886, 2009.

Bréda, N., Huc, R., Granier, A., and Dreyer, E.: Temperate forest trees and stands under severe drought: a review of ecophysiological responses, adaptation processes and long-term consequences, Ann. For. Sci., 63, 625-644, 2006.

Brown, M., Black, T. A., Nesic, Z., Foord, V. N., Spittlehouse, D. L., Fredeen, A. L., Grant, N. J., Burton, P. J., and Trofymow, J. A.: Impact of mountain pine beetle on the net ecosystem production of lodgepole pine stands in British Columbia, Agr. Forest Meteorol., 150, 254-264, doi:10.1016/j.agrformet.2009.11.008, 2010.

Caldwell, M. K., Hawbaker, T. J., Briggs, J. S., Cigan, P. W., and Stitt, S.: Simulated impacts of mountain pine beetle and wildfire disturbances on forest vegetation composition and carbon stocks in the Southern Rocky Mountains, Biogeosciences, 10, 82038222, doi:10.5194/bg-10-8203-2013, 2013.

Carnicer, J., Coll, M., Ninyerola, M., Pons, X., Sánchez, G., and Peñuelas, J.: Widespread crown condition decline, food web disruption, and amplified tree mortality with increased climate change-type drought, P. Natl. Acad. Sci. USA, 108, 1474-1478, 2011.

Chambers, J. Q., Fisher, J. I., Zeng, H. C., Chapman, E. L., Baker, D. B., and Hurtt, G. C.: Hurricane Katrina's carbon footprint on U. S. Gulf Coast forests, Science, 318, 1107-1107, doi:10.1126/science.1148913, 2007.

Chapin, F. S., Matson, P. A., and Vitousek, P. M.: Principles of Terrestrial Ecosystem Ecology, Springer, New York, 2011.

Chen, H., Lu, W., Yan, G., Yang, S., and Lin, G.: Typhoons exert significant but differential impacts on net ecosystem carbon exchange of subtropical mangrove forests in China, Biogeosciences, 11, 5323-5333, doi:10.5194/bg-11-5323-2014, 2014.

Ciais, P., Reichstein, M., Viovy, N., Granier, A., Ogee, J., Allard, V., Aubinet, M., Buchmann, N., Bernhofer, C., Carrara, A., Chevallier, F., De Noblet, N., Friend, A. D., Friedlingstein, P., Grunwald, T., Heinesch, B., Keronen, P., Knohl, A., Krinner, G., Loustau, D., Manca, G., Matteucci, G., Miglietta, F., Ourcival, J. M., Papale, D., Pilegaard, K., Rambal, S., Seufert, G., Soussana, J. F., Sanz, M. J., Schulze, E. D., Vesala, T., and Valentini, R.: Europe-wide reduction in primary productivity caused by the heat and drought in 2003, Nature, 437, 529-533, doi:10.1038/nature03972, 2005.

Clark, K. L., Skowronski, N. S., Gallagher, M. R., Renninger, H., and Schäfer, K. V. R.: Contrasting effects of invasive insects and fire on ecosystem water use efficiency, Biogeosciences, 11, 6509-6523, doi:10.5194/bg-11-6509-2014, 2014.

Dahal, D., Liu, S., and Oeding, J.: The carbon cycle and hurricanes in the United States between 1900 and 2011, Scientific Reports, 4, 5197, doi:10.1038/srep05197, 2014.

DeFries, R. S., Houghton, R. A., Hansen, M. C., Field, C. B., Skole, D., and Townshend, J.: Carbon emissions from tropical deforestation and regrowth based on satellite observations for the 1980s and 1990s, P. Natl. Acad. Sci. USA, 99, 14256-14261, 2002.

Deng, F., Chen, J. M., Pan, Y., Peters, W., Birdsey, R., McCullough, $\mathrm{K}$., and Xiao, J.: The use of forest stand age information in an atmospheric $\mathrm{CO}_{2}$ inversion applied to North America, Biogeosciences, 10, 5335-5348, doi:10.5194/bg-10-5335-2013, 2013.

Desai, A. R., Bolstad, P. V., Cook, B. D., Davis, K. J., and Carey, E. V.: Comparing net ecosystem exchange of carbon dioxide between an old-growth and mature forest in the upper Midwest, USA, Agr. Forest Meteorol., 128, 33-55, doi:10.1016/j.agrformet.2004.09.005, 2005.

De Simon, G., Alberti, G., Delle Vedove, G., Peressotti, A., Zaldei, A., and Miglietta, F.: Short-term cropland responses to temperature extreme events during late winter, Biogeosciences, 10, 5545-5553, doi:10.5194/bg-10-5545-2013, 2013.

Eimers, M. C., Buttle, J., and Watmough, S. A.: Influence of seasonal changes in runoff and extreme events on dissolved organic carbon trends in wetland- and upland-draining streams, Can. J. Fish. Aquat. Sci., 65, 796-808, doi:10.1139/f07-194, 2008.

Ghimire, B., Williams, C. A., Collatz, G. J., Vanderhoof, M., Rogan, J., Kulakowski, D., and Masek, J. G.: Large carbon release legacy from bark beetle outbreaks across Western United States, Glob. Change Biol., 21, 3087-3101, doi:10.1111/gcb.12933, 2015.

Harris, N. L., Brown, S., Hagen, S. C., Saatchi, S. S., Petrova, S., Salas, W., Hansen, M. C., Potapov, P. V., and Lotsch, A.: Baseline map of carbon emissions from deforestation in tropical regions, Science, 336, 1573-1576, 2012. 
Hicke, J. A., Allen, C. D., Desai, A. R., Dietze, M. C., Hall, R. J., Hogg, E. H., Kashian, D. M., Moore, D., Raffa, K. F., Sturrock, R. N., and Vogelmann, J.: Effects of biotic disturbances on forest carbon cycling in the United States and Canada, Glob. Change Biol., 18, 7-34, doi:10.1111/j.1365-2486.2011.02543.x, 2012.

Huang, C. Q., Coward, S. N., Masek, J. G., Thomas, N., Zhu, Z. L., and Vogelmann, J. E.: An automated approach for reconstructing recent forest disturbance history using dense Landsat time series stacks, Remote Sens. Environ., 114, 183-198, doi:10.1016/j.rse.2009.08.017, 2010.

IPCC: Climate Change 2013: The Physical Science Basis. Contribution of Working Group I to the Fifth Assessment Report of the Intergovernmental Panel on Climate Change, Cambridge University Press, Cambridge, United Kingdom and New York, NY, USA, 2013.

Jiang, H., Deng, Q., Zhou, G., Hui, D., Zhang, D., Liu, S., Chu, G., and Li, J.: Responses of soil respiration and its temperature/moisture sensitivity to precipitation in three subtropical forests in southern China, Biogeosciences, 10, 3963-3982, 10.5194/bg-10-3963-2013, 2013.

Johnson, D. W. and Curtis, P. S.: Effects of forest management on soil $\mathrm{C}$ and $\mathrm{N}$ storage: meta analysis, Forest Ecol. Manag., 140, 227-238, 10.1016/s0378-1127(00)00282-6, 2001.

Jung, M., Reichstein, M., and Bondeau, A.: Towards global empirical upscaling of FLUXNET eddy covariance observations: validation of a model tree ensemble approach using a biosphere model, Biogeosciences, 6, 2001-2013, doi:10.5194/bg-6-20012009, 2009.

Kennedy, R. E., Yang, Z. G., and Cohen, W. B.: Detecting trends in forest disturbance and recovery using year ly Landsat time series: 1. LandTrendr - Temporal segmentation algorithms, Remote Sens. Environ., 114, 2897-2910, doi:10.1016/j.rse.2010.07.008, 2010.

Kurz, W. A., Dymond, C. C., Stinson, G., Rampley, G. J., Neilson, E. T., Carroll, A. L., Ebata, T., and Safranyik, L.: Mountain pine beetle and forest carbon feedback to climate change, Nature, 452, 987-990, doi:10.1038/nature06777, 2008a.

Kurz, W. A., Stinson, G., Rampley, G. J., Dymond, C. C., and Neilson, E. T.: Risk of natural disturbances makes future contribution of Canada's forests to the global carbon cycle highly uncertain, P. Natl. Acad. Sci. USA, 105, 1551-1555, 2008b.

Law, B. E., Turner, D., Campbell, J., Sun, O., Van Tuyl, S., Ritts, W., and Cohen, W.: Disturbance and climate effects on carbon stocks and fluxes across Western Oregon USA, Glob. Change Biol., 10, 1429-1444, 2004.

Li, F., Bond-Lamberty, B., and Levis, S.: Quantifying the role of fire in the Earth system - Part 2: Impact on the net carbon balance of global terrestrial ecosystems for the 20th century, Biogeosciences, 11, 1345-1360, doi:10.5194/bg-11-1345-2014, 2014.

Liu, S. G., Bond-Lamberty, B., Hicke, J. A., Vargas, R., Zhao, S. Q., Chen, J., Edburg, S. L., Hu, Y. M., Liu, J. X., McGuire, A. D., Xiao, J. F., Keane, R., Yuan, W. P., Tang, J. W., Luo, Y. Q., Potter, C., and Oeding, J.: Simulating the impacts of disturbances on forest carbon cycling in North America: Processes, data, models, and challenges, J. Geophys. Res., 116, G00K08, 10.1029/2010jg001585, 2011.

Liu, Y., Zhou, Y., Ju, W., Wang, S., Wu, X., He, M., and Zhu, G.: Impacts of droughts on carbon sequestration by China's terrestrial ecosystems from 2000 to 2011, Biogeosciences, 11, 2583-2599, doi:10.5194/bg-11-2583-2014, 2014.

Luyssaert, S., Schulze, E. D., Borner, A., Knohl, A., Hessenmoller, D., Law, B. E., Ciais, P., and Grace, J.: Oldgrowth forests as global carbon sinks, Nature, 455, 213-215, doi:10.1038/nature07276, 2008.

Magnani, F., Mencuccini, M., Borghetti, M., Berbigier, P., Berninger, F., Delzon, S., Grelle, A., Hari, P., Jarvis, P. G., Kolari, P., Kowalski, A. S., Lankreijer, H., Law, B. E., Lindroth, A., Loustau, D., Manca, G., Moncrieff, J. B., Rayment, M., Tedeschi, V., Valentini, R., and Grace, J.: The human footprint in the carbon cycle of temperate and boreal forests, Nature, 447, 848-850, doi:10.1038/nature05847, 2007.

Masek, J. G., Goward, S. N., Kennedy, R. E., Cohen, W. B., Moisen, G. G., Schleeweis, K., and Huang, C. Q.: United States forest disturbance trends observed using Landsat time series, Ecosystems, 16, 1087-1104, doi:10.1007/s10021-013-9669-9, 2013.

Mathys, A., Black, T. A., Nesic, Z., Nishio, G., Brown, M., Spittlehouse, D. L., Fredeen, A. L., Bowler, R., Jassal, R. S., Grant N. J., Burton, P. J., Trofymow, J. A., and Meyer, G.: Carbon balance of a partially harvested mixed conifer forest following mountain pine beetle attack and its comparison to a clear-cut, Biogeosciences, 10, 5451-5463, doi:10.5194/bg-10-5451-2013, 2013.

McCarthy, H. R., Oren, R., Kim, H. S., Johnsen, K. H., Maier, C., Pritchard, S. G., and Davis, M. A.: Interaction of ice storms and management practices on current carbon sequestration in forests with potential mitigation under future $\mathrm{CO}_{2}$ atmosphere, J. Geophys. Res., 111, D15103, doi:10.1029/2005jd006428, 2006.

McDowell, N. G.: Mechanisms linking drought, hydraulics, carbon metabolism, and vegetation mortality, Plant Physiol., 155, 10511059, 2011.

Meddens, A. J., Hicke, J. A., Macalady, A. K., Buotte, P. C., Cowles, T. R., and Allen, C. D.: Patterns and causes of observed piñon pine mortality in the southwestern United States, New Phytol. 206, 91-97, 2015.

Meir, P., Mencuccini, M., and Dewar, R. C.: Drought-related tree mortality: addressing the gaps in understanding and prediction, New Phytol., 207, 28-33, 2015.

Nadelhoffer, K. J., Emmett, B. A., Gundersen, P., Kjonaas, O. J., Koopmans, C. J., Schleppi, P., Tietema, A., and Wright, R. F.: Nitrogen deposition makes a minor contribution to carbon sequestration in temperate forests, Nature, 398, 145-148, doi:10.1038/18205, 1999.

Nave, L. E., Vance, E. D., Swanston, C. W., and Curtis, P. S.: Harvest impacts on soil carbon storage in temperate forests, Forest Ecol. Manag., 259, 857-866, doi:10.1016/j.foreco.2009.12.009, 2010.

Odum, E. P.: The strategy of ecosystem development, Science, 164 , 262-270, 1969.

Page, S. E., Siegert, F., Rieley, J. O., Boehm, H.-D. V., Jaya, A., and Limin, S.: The amount of carbon released from peat and forest fires in Indonesia during 1997, Nature, 420, 61-65, 2002.

Pan, Y., Chen, J. M., Birdsey, R., McCullough, K., He, L., and Deng, F.: Age structure and disturbance legacy of North American forests, Biogeosciences, 8, 715-732, doi:10.5194/bg-8-7152011, 2011.

Piayda, A., Dubbert, M., Rebmann, C., Kolle, O., Costa e Silva, F., Correia, A., Pereira, J. S., Werner, C., and Cuntz, M.: Drought 
impact on carbon and water cycling in a Mediterranean Quercus suber L. woodland during the extreme drought event in 2012, Biogeosciences, 11, 7159-7178, doi:10.5194/bg-11-7159-2014, 2014.

Pokrovsky, O. S., Shirokova, L. S., Kirpotin, S. N., Kulizhsky, S. P., and Vorobiev, S. N.: Impact of western Siberia heat wave 2012 on greenhouse gases and trace metal concentration in thaw lakes of discontinuous permafrost zone, Biogeosciences, 10, 5349-5365, doi:10.5194/bg-10-5349-2013, 2013.

Qu, L. P., Chen, J. Q., Dong, G., Jiang, S. C., Li, L. H., Guo, J. X., and Shao, C. L.: Heat waves reduce ecosystem carbon sink strength in a Eurasian meadow steppe, Environ. Res., 144, 3948, doi:10.1016/j.envres.2015.09.004, 2016.

Raffa, K. F., Aukema, B. H., Bentz, B. J., Carroll, A. L., Hicke, J. A., Turner, M. G., and Romme, W. H.: Cross-scale drivers of natural disturbances prone to anthropogenic amplification: The dynamics of bark beetle eruptions, Bioscience, 58, 501-517, doi:10.1641/b580607, 2008.

Reichstein, M., Ciais, P., Papale, D., Valentini, R., Running, S., Viovy, N., Cramer, W., Granier, A., Ogee, J., and Allard, V.: Reduction of ecosystem productivity and respiration during the European summer 2003 climate anomaly: a joint flux tower, remote sensing and modelling analysis, Glob. Change Biol., 13, 634$651,2007$.

Reichstein, M., Bahn, M., Ciais, P., Frank, D., Mahecha, M. D., Seneviratne, S. I., Zscheischler, J., Beer, C., Buchmann, N., Frank, D. C., Papale, D., Rammig, A., Smith, P., Thonicke, K., van der Velde, M., Vicca, S., Walz, A., and Wattenbach, M.: Climate extremes and the carbon cycle, Nature, 500, 287-295, doi:10.1038/nature12350, 2013.

Schwalm, C. R., Williams, C. A., Schaefer, K., Arneth, A., Bonal, D., Buchmann, N., Chen, J. Q., Law, B. E., Lindroth, A., Luyssaert, S., Reichstein, M., and Richardson, A. D.: Assimilation exceeds respiration sensitivity to drought: A FLUXNET synthesis, Glob. Change Biol., 16, 657-670, doi:10.1111/j.13652486.2009.01991.x, 2010.

Seidl, R., Schelhaas, M.-J., Rammer, W., and Verkerk, P. J.: Increasing forest disturbances in Europe and their impact on carbon storage, Nature Climate Change, 4, 806-810, 2014.

Turetsky, M. R., Benscoter, B., Page, S., Rein, G., van der Werf, G. R., and Watts, A.: Global vulnerability of peatlands to fire and carbon loss, Nat. Geosci., 8, 11-14, 2015.

Turner, M. G., Collins, S. L., Lugo, A. E., Magnuson, J. J., Rupp, T. S., and Swanson, F. J.: Disturbance dynamics and ecological response: The contribution of long-term ecological research, Bioscience, 53, 46-56, doi:10.1641/00063568(2003)053[0046:ddaert]2.0.co;2, 2003.

Wang, W., Xiao, J., Ollinger, S. V., Desai, A. R., Chen, J., and Noormets, A.: Quantifying the effects of harvesting on carbon fluxes and stocks in northern temperate forests, Biogeosciences, 11, 6667-6682, doi:10.5194/bg-11-6667-2014, 2014.

Williams, C. A., Collatz, G. J., Masek, J., Huang, C. Q., and Goward, S. N.: Impacts of disturbance history on forest carbon stocks and fluxes: Merging satellite disturbance mapping with forest inventory data in a carbon cycle model framework, Remote Sens. Environ., 151, 57-71, doi:10.1016/j.rse.2013.10.034, 2014.

Xiao, J. F., Zhuang, Q. L., Baldocchi, D. D., Law, B. E., Richardson, A. D., Chen, J. Q., Oren, R., Starr, G., Noormets, A., Ma,
S. Y., Verma, S. B., Wharton, S., Wofsy, S. C., Bolstad, P. V., Burns, S. P., Cook, D. R., Curtis, P. S., Drake, B. G., Falk, M., Fischer, M. L., Foster, D. R., Gu, L. H., Hadley, J. L., Hollinger, D. Y., Katul, G. G., Litvak, M., Martin, T. A., Matamala, R., McNulty, S., Meyers, T. P., Monson, R. K., Munger, J. W., Oechel, W. C., Paw U, K. T., Schmid, H. P., Scott, R. L., Sun, G., Suyker, A. E., and Torn, M. S.: Estimation of net ecosystem carbon exchange for the conterminous United States by combining MODIS and AmeriFlux data, Agr. Forest Meteorol., 148, 1827 1847, doi:10.1016/j.agrformet.2008.06.015, 2008.

Xiao, J. F., Zhuang, Q. L., Liang, E. Y., McGuire, A. D., Moody, A., Kicklighter, D. W., Shao, X. M., and Melillo, J. M.: Twentiethcentury droughts and their impacts on terrestrial carbon cycling in China, Earth Interact., 13, 1-31, doi:10.1175/2009ei275.1, 2009.

Xiao, J. F., Zhuang, Q. L., Law, B. E., Baldocchi, D. D., Chen, J. Q., Richardson, A. D., Melillo, J. M., Davis, K. J., Hollinger, D. Y., Wharton, S., Oren, R., Noormets, A., Fischer, M. L., Verma, S. B., Cook, D. R., Sun, G., McNulty, S., Wofsy, S. C., Bolstad, P. V., Burns, S. P., Curtis, P. S., Drake, B. G., Falk, M., Foster, D. R., Gu, L. H., Hadley, J. L., Katulk, G. G., Litvak, M., Ma, S. Y., Martinz, T. A., Matamala, R., Meyers, T. P., Monson, R. K., Munger, J. W., Oechel, W. C., Paw U, K. T., Schmid, H. P., Scott, R. L., Starr, G., Suyker, A. E., and Torn, M. S.: Assessing net ecosystem carbon exchange of U.S. terrestrial ecosystems by integrating eddy covariance flux measurements and satellite observations, Agr. Forest Meteorol., 151, 60-69, doi:10.1016/j.agrformet.2010.09.002, 2011.

Xiao, J. F., Ollinger, S. V., Frolking, S., Hurtt, G. C., Hollinger, D. Y., Davis, K. J., Pan, Y. D., Zhang, X. Y., Deng, F., Chen, J. Q., Baldocchi, D. D., Law, B. E., Arain, M. A., Desai, A. R., Richardson, A. D., Sun, G., Amiro, B., Margolis, H., Gu, L. H., Scott, R. L., Blanken, P. D., and Suyker, A. E.: Data-driven diagnostics of terrestrial carbon dynamics over North America, Agr. Forest Meteorol., 197, 142-157, doi:10.1016/j.agrformet.2014.06.013, 2014.

Yue, C., Ciais, P., Luyssaert, S., Cadule, P., Harden, J., Randerson, J., Bellassen, V., Wang, T., Piao, S. L., Poulter, B., and Viovy, N.: Simulating boreal forest carbon dynamics after stand-replacing fire disturbance: insights from a global process-based vegetation model, Biogeosciences, 10, 8233-8252, doi:10.5194/bg-108233-2013, 2013.

Zeppel, M. J., Anderegg, W. R., and Adams, H. D.: Forest mortality due to drought: latest insights, evidence and unresolved questions on physiological pathways and consequences of tree death, New Phytol., 197, 372-374, 2013.

Zeppel, M. J. B., Wilks, J. V., and Lewis, J. D.: Impacts of extreme precipitation and seasonal changes in precipitation on plants, Biogeosciences, 11, 3083-3093, doi:10.5194/bg-11-3083-2014, 2014.

Zhao, M. S. and Running, S. W.: Drought-induced reduction in global terrestrial net primary production from 2000 through 2009, Science, 329, 940-943, doi:10.1126/science.1192666, 2010.

Zhao, M. S., Heinsch, F. A., Nemani, R. R., and Running, S. W.: Improvements of the MODIS terrestrial gross and net primary production global data set, Remote Sens. Environ., 95, 164-176, doi:10.1016/j.rse.2004.12.011, 2005. 
Zhou, D. C., Zhao, S. Q., Liu, S., and Oeding, J.: A meta-analysis on the impacts of partial cutting on forest structure and carbon storage, Biogeosciences, 10, 3691-3703, doi:10.5194/bg-10-36912013, 2013a.

Zhou, D. C., Liu, S. G., Oeding, J., and Zhao, S. Q.: Forest cutting and impacts on carbon in the eastern United States, Scientific Reports, 3, 3547, doi:10.1038/srep03547, 2013b.
Zhu, Z. and Woodcock, C. E.: Continuous change detection and classification of land cover using all available Landsat data, Remote Sens. Environ., 144, 152-171, doi:10.1016/j.rse.2014.01.011, 2014. 